\title{
Gender and Philology's Uncommon Sense
}

Jacqueline Vayntrub, Laura Quick, and Ingrid Lilly

Philology, once central to the humanities - a discipline that spawned many other fields such as comparative literature, linguistics, anthropology, religious studies, folklore studies - has now become an uncommon subject to which one attaches oneself. ${ }^{1}$ The historicist, positivist aims of philology seem directly at odds with the limitations of knowledge admitted now by most humanistic disciplines. ${ }^{2}$ In order to make any sense of what philology might have to do with attention to gender in ancient texts, one must ask what in fact is the method of philology? Ask any well-respected and rigorously trained philologist and they will likely throw their hands up at such a question. The German classical philologist, Ulrich von Wilamowitz-Moellendorff, who attacked Nietzsche's own critique of philology's historical-critical method, notoriously compared philological method to fishing: "About this prized 'philological method'? There simply isn't one-no more than a method to catch a fish. The whale is harpooned, the herring caught in a net, flounders are stomped upon, ${ }^{3}$ the salmon speared, the trout caught on a fly. Where do you find the method to catch a fish?"4

1. James Turner, Philology: The Forgotten Origins of the Modern Humanities

(Princeton: Princeton University Press, 2014).

2. Sheldon Pollock: "I have heard [philology] confused with phrenology, and even for those who know better, philology shares something of the disrepute of that nineteenthcentury pseudoscience;" "Future Philology? The Fate of a Soft Science in a Hard World," Critical Inquiry 35:4 (2009): 931-961.

${ }^{3}$ See W.A. Schröder, "Der 'getretene Butt': Aelian und Wilamowitz," Rheinisches Museum für Philologie 133 (1990): 415-416.

${ }^{4}$. Trans. William M. Calder III, "Ulrich von Wilamowitz-Moellendorff to Wolfgang Schedewaldt on the Classic," Greek, Roman and Byzantine Studies 16 (1975): 451457, here 452. Wiliamowitz-Moellendorff was almost certainly humorously imitating 
The method, as Wilamowitz-Moellendorff described it, seemed to be more than just ad-hoc, or make it up as you go along. The method is selfconsciously not-method. Philologists are not used to answering self-reflective questions such as, "What is your method?" These questions run counter to conventional philological training. There appear to be important methodological reasons for this lack of self-reflection-reasons that involve the philologist's erasure of the entire history of interpretive tradition (including him or herself) to seek the unblemished, singular historical context of textualized language. ${ }^{5}$ But we return to the question at hand: what is the method of philology?

Whenever one does hear some sort of answer to this question of identifying philological method, it is frequently some version of "common sense"-an impoverished substitute for a clearly articulated epistemology. "Common sense" as philological method rears its head in class discussionsdiscussions which inevitably stray from the question of the language towards questions of meaning-and is encountered in methodology sections of dissertations and books, sometimes in support of claims that the philologist had succeeded in freeing him or herself from the strictures of previous interpretive models. ${ }^{6}$ Common sense is wielded as a weapon against ungrounded literary

Ovid's lament on the lack of method in attracting a partner: "I was on the point of ending here; but let me add that women are things of many moods [...] These fish are caught with spears, those with hooks; these ones are dragged with taut ropes in bulging nets. Do not let one method suit all." ( $A A$ 1.755-765). See William M. Calder III, “"Credo gegen Credo; Arbeit gegen Arbeit; Anschauung gegen Anshauung': Ulrich von Wilamowitz-Moellendorff contra Eduard Meyer," in Eduard Meyer: Leben und Leistung eines Universalhistorikers, ed. William M. Calder III and Alexander Demandt (Leiden: Brill, 1990), 41-73, here 65.

5. Sheldon Pollock, "Philology in Three Dimensions," Postmedieval: A Journal of Medieval Cultural Studies 5 (2014): 398-413.

${ }^{6}$. Glibly, one might turn to a popularizing work in imparting the "basics" of biblical 
and theological interpretations. While these broad theoretical interpretations of the ancient text could be presented as relevant to contemporary ideas, the philologist positions themselves in contrast to this approach; they ground themselves in an understanding of the text in language, and thus the original meaning of the text. Leaving aside, for the moment, the fact that as a method, common sense assumes a single, correct historical meaning of a text's language located in the objective understanding of the philologist, one's own common sense must be, necessarily, highly subjective: how else does one arrive at the single correct interpretation of ancient language without imposing elements of their own subject positions?

If philology is necessarily an exercise in rigorous comparison between the culture embedded in the ancient language of the text and that which is embedded in one's own linguistically shaped worldview, how can the results of such a comparison be anything but incomplete and historically contingent? This

philology, Do it Yourself Hebrew and Greek: A Guide to Biblical Language Tools, by Edward W. Goodrich (Second ed., Multnomah Press, 1980) whose twelfth lesson in this guide is entitled, "Common Sense Rules for Interpretation." The author advises his reader, "Sooner or later...you are going to stop long enough in your Bible study to ask yourself, 'Am I doing it right? Are there rules to go by for interpreting the Bible?' There sure are... since the Reformation...just about everybody worth his salt espouses the 'Grammatico-Historical system...I prefer to call it the 'Common Sense' method." As a more serious case in point, one might refer to the essays collected in the 2006 volume of the journal Hebrew Studies, with such programmatic titles as Martin Ehrensvärd, "Why Biblical Texts Cannot Be Dated Linguistically," HS 47 (2006): 177189; and Avi Hurvitz, "The Recent Debate on Late Biblical Hebrew: Solid Data, Experts' Opinions, and Inconclusive Arguments," HS 47 (2006): 191-210. Philology construed narrowly in terms of historical Hebrew grammar and the related possibilities to date biblical texts linguistically has developed into two unmoving, binary poles, with each side claiming their own self-evident veracity — and with fairly low stakes as far as the wider Humanistic disciplines are concerned. 
was a crucial point of departure for the organization of the panel at the 2018 Annual Meeting of the Society of Biblical Literature in Denver, Colorado, and which subsequently gave rise to the essays in this volume. The study of gender in antiquity, through the language of its textual products, is not a marginal concern of specialized hermeneutics lying outside the scope of rigorous philology. Much to the contrary, gender is a surface-marked element in ancient Hebrew and in all Semitic languages. And of course, once a philologist is trained to understand language and text as products of their time and place, one cannot help but see that even the very categories and frameworks inherited and reimagined by the philologist are also products of one's time and place, and, significantly, one's social positioning. The very pedagogical tools through which philology is perpetuated-grammars, lexica, wordbooks, commentaries-are determined through particular lenses, dictated by frameworks natural to those who brought them into being and oblivious to other, marginalized perspectives. This collection of essays on the Philology of Gender seeks to widen the philological lens in one particular marginalized area, but also seeks to encourage others to reform philological practices and frameworks from within as well. In the spirit of reflecting on the inherited frameworks of the philologist and offering a genealogy of its method, this foreword will present a brief history of "common sense" as a philological practice. $^{7}$ In doing so, the hope is that philology's methods and practices will experience greater transparency and clarity, that they can become a rigorous reflected upon uncommon sense, actively retooled by the scholar.

\footnotetext{
${ }^{7}$ See also Esther Brownsmith's essay in this volume, which provides a focused sociology of knowledge in the field by considering how and why certain types of metaphors are deemed important for the study of biblical philology, uncovering a bias in the social positioning of the interpreters. Biblical studies, after all, has historically been a male-dominated subject, and this is reflected in the concerns of traditional scholarship.
} 
The historicist aims of the biblical philologist, and the pretense of an approach free of external interpretive models goes back to Spinoza. In his Theological-Political Treatise, Spinoza tells us that the only true method for studying the biblical text is to examine the text in its own manner of expression: "Knowledge of scripture is to be sought only from scripture." The difficulty in this method, Spinoza tells us, is that deep knowledge of the text's language is essential to performing the philologist's task: a "complete knowledge of the Hebrew language" would be fundamental to understanding the meaning of the text. ${ }^{8}$ The more we know about the original manner of expression, the closer we can approach the text's meaning. The task of philology, therefore, is like approaching the horizon of the past but never quite arriving. And at times, the closer we approach, and the more layers of interpretive tradition we peel away, the farther the text's meaning can seem, because its meaning, without our own recognizable and comfortable categories, becomes all the more alien to the contemporary reader.

For example, in her essay, Shawna Dolansky nuances our understanding

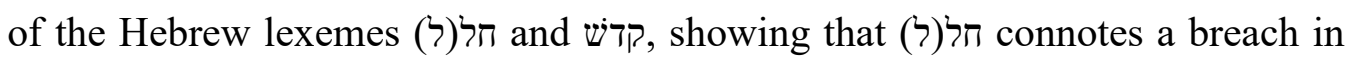
wholeness that operates on a continuum relative to status and circumstance, rather than functioning merely as a simple opposite of Pדש Sensitivity to the ways in which gender functions in the worldview of the biblical authors and informs the language which they utilize is essential to properly interpreting these culturally specific terms. Only by moving away from the anachronistic imposition of the binary "sacred/profane" can we fully appreciate the range of meanings evoked by קדש חל חל (ל). A rigorous "philology of gender" is thus essential to our translational practice.

\footnotetext{
${ }^{8}$ Benedictus de Spinoza, The Collected Works of Spinoza, volume 2, edited and translated by Edwin Curley (Princeton and Oxford: Princeton University Press, 2016), $180(7.43-46)$.
} 
Spinoza admits that the knowledge gleaned from such reading will always be partial: the biblical authors were writing for their own audience, not for us. The biblical authors could assume shared knowledge of language and culture: "The meaning of many nouns and verbs which occur in the Bible is either completely unknown or is disputed," and "we lack, not only all these things, but also and especially, a phraseology of this language. For time, the devourer, has obliterated from the memory of men almost all the idioms and manners of speaking peculiar to the Hebrew nation." 9 The task of historicist interpreters of ancient texts, according to Spinoza, is to recover these words and expressions from the ravages of time, to find verum sensum, the true sense, of a passage. ${ }^{10}$ As philologists, we are only as successful as we are able to cultivate proximity to the language and its meaning, free of any other interpretive models. But is such a non-method even feasible? What assumptions do we make when we say we approach the text without barriers between the worldview of the ancient text and our own understanding of culture-inlanguage? That is to say, what do we mean by "common sense," and what is its place the inherited practices of philology? ${ }^{11}$

9. Ibid.

${ }^{10}$. We have taken inspiration from Sheldon Pollock's reading of Spinoza's tractatus as a foundational text in philological method: “The 'true' meaning that Spinoza references can be discovered only if we readers 'free our minds' of the interpretations of other, earlier members of the tradition," in "Philology in Three Dimensions," Postmedieval: A Journal of Medieval Cultural Studies 5:4 (2014): 398-413.

${ }^{11}$. Contemporary biblical textual criticism is a good specimen for this question. Its values and practices of scientific precision appeal to rationalized traditions about language, which in itself, is a "senseless" approach to language that can overextend itself and yield "common sense" remarks like "the text is a mess," but too, these selfdeclared scientists of texts also admit their use of common sense in their evaluations in remarks like "the reading does not make sense." Such appeals to common sense are not usually the result of critical, reflective engagement with historical interpretive 
The second and definitive edition of Giambattista Vico's Scienza Nuova (New Science), published in Naples in 1730, set out to establish a new discipline that combined meditation on ideas, philosophy, and what he identified as the study of "textual and other evidence constituting the facts"philology. ${ }^{12}$ Vico held to an evolutionist scheme of the development of language and culture. For him, early humans were metaphor-speaking poets; 'primitive man' was not as capable of theorizing as 'modern man' was. ${ }^{13}$ But

possibilities but are most often reflexes of modern, normative experiences conditioning and limiting one's "sense" for what is possible. See Lilly's discussion of genology in text-critical study in Ingrid E. Lilly, “'Like the Vision': Temple Tours, Comparative Genre, and Scribal Composition in Ezekiel 43," in Ezekiel: Current Debates and Future Directions, ed. William A. Tooman and Penelope Barter (Tübingen: Mohr Siebeck, 2017), 210-32.

${ }^{12}$. Giorgio Tagliacozzo and Hayden V. White, Giambattista Vico: An International Symposium (Baltimore: Johns Hopkins Press, 1969), 93. For further discussion on Vico, his evolutionist framework, and the persistence of these ideas in biblical philology, particularly in the theorization of biblical poetry, see Jacqueline Vayntrub, Beyond Orality: Biblical Poetry on its Own Terms (London: Routledge, 2019), 29-30, 46-49.

12. In biblical studies this sort of approach was taken to its fullest articulation with the problematic view associated with $\mathrm{H}$. Wheeler Robinson for the existence of what has what has variously been called "corporate personality" or "corporate responsibility" in ancient Israel. Based on texts in which the whole family of an individual who has committed a crime is punished (especially Joshua 7 and 2 Samuel 21), Robinson had argued that in the biblical world the individual was not distinguished from the wider group from which he or she belonged. See H. Wheeler Robinson, The Christian Doctrine of Man (3rd edn; Edinburgh: T\&T Clark, 1926); idem, Corporate Responsibility to Ancient Israel (rev edn; Edinburgh: T\&T Clark, 1981). Wheeler Robinson drew in particular upon the work of Émile Durkheim, who employed the notion of a "primitive psychology" for ancient peoples on the basis of an opposition between pre-logical and logical mentalities in the development of man. This prevalent 
language was a civilizing force, and that which was originally metaphor and poetic developed into a colorless and prosaic discourse. ${ }^{14}$ It is important to note that, for all its later abuses in colonialist frameworks, Vico did not mean primitive in a disparaging sense. He believed that the metaphors of early language could reveal common or universal truths. He called this "a common mental language." In his scheme, one language and text culture just happens to be on one or another point of the developmental trajectory; it is the shared, common experience of the development of language and literature that enabled one to encounter the language and text traditions of another and make sense of them:

Uniform ideas originating among entire peoples unknown to each other must have a common ground of truth ${ }^{15} \ldots$ vulgar

model, which related cultural and structural "simplicity" to evolutionary priority, arose in conjunction with the mid eighteenth-century interest in originality and genius, embedding itself within humanistic discourse during the rise of nineteenth-century historicism. This model is also apparent in the concern of early source critics to trace theological developments through the various literary stages which apparently exist in the Torah and which in some way came be seen to parallel the evolution of the critics' own theological position, so Protestantism in nineteenth-century Germany. The more "primitive" documents, J and E, and the overly legalistic D and P, are ultimately superseded by the "superior" theological ethic of the later Classical Prophets, just as the modern-day Protestant reformers had transformed contemporary Christianity. Similarly, the move from source-critical theories to form-critical ones may be seen in the larger context of the shift from the nineteenth-century theorizing to the more synchronic intellectual paradigms of the twentieth century and their tendency to understand phenomena through the analysis of function and form: it is thus related to both structuralist and formalist models.

${ }^{14}$ See further discussion of this in Vayntrub, Beyond Orality, 29.

15. Giambattista Vico, The New Science of Giambattista Vico: Revised Translation of the Third Edition (1744), translated by Thomas Goddard Bergin and Max Harold Fisch 
traditions must have had public grounds of truth, by virtue of which they came into being and were preserved by entire peoples over periods of time. ${ }^{16}$

But it is important to note that even the notion of "common sense," the nonmethod of the philologist, is itself a method with a history. This notion, as Vico articulates it, comes about through a particular understanding of language, that there is always something mutually intelligible and therefore shared from one human language to another that allows the philologist to find an access pointa point of common sense. ${ }^{17}$ As Vico writes:

Philosophy contemplates reason, whence comes knowledge of the true; philology observes the authority of human choice, whence comes consciousness of the certain...Human choice, by its nature most uncertain, is made certain and determined by the common sense of men...Uniform ideas originating among entire peoples unknown to each other must have a common ground of truth. This axiom is a great principle which establishes the common sense of the human race as the criterion taught to the nations by divine providence to define what is certain in the natural law of nations. ${ }^{18}$

(Ithaca, NY: Cornell University Press, 1948), sections 211-212.

${ }^{16}$. Ibid., sections 215-216.

${ }^{17}$ In Truth and Method, Hans-Georg Gadamer explains that Vico's sensus communis is not universalism or natural law, but the particular "sense of what is right and of the common good that is to be found in all men... a sense that is acquired through living in the community and determined by its structures and aims," Second, revised edition. Translated by Joel Weinsheimer and Donald G. Marshall (London; New York: Continuum, 2004), 20. 
A brief note on the sense component of common sense is also in order. Here, intellectual history can only yield us more of a counter-genealogy where senses and the non-rational faculties of the body became the negative conceptthe epistemological problem, in some cases elevated to the language of sinagainst which all positivist, Enlightenment projects could be established. The aim-whether in Spinoza's verum sensum or Vico's sensus communis to find a shared sense between the philologist and the ancient text underscores an important recent effort - and perhaps a very old idea at the heart of philological inquiry - to center embodiment in a corporeal philology. ${ }^{19}$ The inherited framework of biblical scholarship tends towards a modern anthropocentric, androcentric lens, where nuances of ancient conceptions of gender and the body are lost.

${ }^{18}$. Vico, The New Science, sections 138, 141, 144-145.

${ }^{19}$ See Edward W. Said, "Vico on the Discipline of Bodies and Texts," MLN 91/5 (1976): 817-826. Recently, in biblical studies, see HeBAI 2 (2013) on "New Perspectives on Body and Religion," edited by Francesca Stavrakopoulou and Marti Nissinen, and Joan E. Taylor (ed.), The Body in Biblical, Christian, and Jewish Texts (LSTS 85; London: T\&T Clark, 2015); Ingrid Lilly, “Ruah Embodied-Job’s Internal Disease from the Perspective of Mesopotamian Medicine," in Borders: Terminologies, Ideologies and Performances, ed. Annette Weissenrieder (Tubingen: Mohr Siebeck, 2016), 323-336; David Lambert, "Refreshing Philology: James Barr, Supersessionism, and the State of Biblical Words," BI 24 (2016): 332-356; Matthew Suriano, A History of Death in the Hebrew Bible (Oxford: Oxford University Press, 2018); Jacqueline Vayntrub, "Like Father, Like Son: Theorizing Transmission in Biblical Literature," HeBAI 7/4 (2019): 500-526; Ingrid E. Lilly, Anatomy of the Self: Cultural Histories of Embodiment in the Hebrew Bible (Oxford: Oxford University Press, forthcoming); Francesca Stavrakopoulou (ed.), Life and Death: Social Perspectives on Biblical Bodies (London: Bloomsbury T\&T Clark, forthcoming); Laura Quick, Dress, Adornment and the Body in the Hebrew Bible (Oxford: Oxford University Press, forthcoming). 
It is now clearer than ever, in the humanities more broadly and in biblical studies, that not everyone shares the same access points. When approaching antiquity through one's own linguistically embedded cultural knowledge, this sense is not common, but much more frequently, uncommon. There is a growing trend towards accounting for the subject positions of gender, race, class, and ability. ${ }^{20}$ Likewise, there has been a trend towards critical selfreflection on biblical philology, its history and its methods. ${ }^{21}$ In this volume, we take up this task through a specific access point: gender. Esther Brownsmith's dissertation project expands the field of feminist biblical studies by uncovering a long overlooked, extended cognitive metaphor that shapes numerous biblical texts: the metaphor WOMAN IS FOOD. Due to the felicity of this project in the context of this volume, Brownsmith was invited to foreground the essays with a

${ }^{20}$ In 2012, the Society of Biblical Literature announced a new program unit, "Metacriticism in Biblical Scholarship," with the aim of interrogating the presuppositions and agendas that underlie scholarship on the Hebrew Bible.

${ }^{21}$ For recent incisive approaches see e.g., Michael Legaspi, The Death of Scripture and the Rise of Biblical Studies (Oxford: Oxford University Press, 2010); David Lambert, How Repentance Became Biblical: Judaism, Christianity, and the Interpretation of Scripture (Oxford: Oxford University Press, 2015); idem, "Refreshing Philology;" Hindy Najman, "Ethical Reading: The Transformation of the Text and the Self," JTS 68 (2017): 507-529; and Vayntrub, Beyond Orality. The increasing (re)turn toward biblical philology and the sociology of disciplinary knowledge is itself demonstrated by the Society of Biblical Literature program unit which co-hosted the panel where these essays originated, "Philology in Hebrew Studies" (alongside the "Gender, Sexuality, and the Bible" program unit). "Renewed Philology," an international working group of scholars in biblical studies whose work reflects critically on the intellectual frameworks brought to bear in philological practice, provides a platform for a number of research projects, workshops, and conferences. See https://renewedphilology.yale.edu 
brief study, "Mind the Gap: An Introduction to Biblical Philology, Gender, and the Two Mothers," focused on the implications of gender for the study of biblical metaphor, and how its study fails to attend to a number of gendered metaphors in Biblical Hebrew. The operation of gendered metaphor in ethnophysiology comes to the fore in Ingrid Lilly's essay, "The Fertility of Bones: Towards a Corporeal Philology of Reproduction." Addressing the scholarly inattention to male fertility in the Hebrew Bible, Lilly draws on insights from kinship studies and medical anthropology, setting the biblical texts in their ancient Near Eastern literary and cultural context to argue that wetness in bones indicates male fertility, while dryness indicates infertility. She demonstrates how a bodily substance of kinship is both conceptualized in medical metaphors for male reproductive health, and how it circulates linguistically in rhetoric, semantics, and transformational grammar.

We have already seen how this sort of approach is fruitful in the lexicalsematic study of Dolansky, whose sensitivity to the dimensions of gender and חל(ל) anthropology in ancient Israelite thought are essential for understanding and קדש. Similarly, Sarah Shectman, in her essay "The Priestly Language of Gender," illuminates the precise technical usage of gender-specific and genderneutral language employed by the Priestly Source, in which $\mathrm{P}$ seems to recognize the difference between biological sex and gender related to personhood, something more akin to what we might term socially constructed gender. Semantics are also at the heart of Laura Quick's essay, "My Lord the Queen: Gender Discord in Comparative Perspective," which adds a comparative semantic approach to Comparative Semitics, which typically focuses upon one of the major subsystems of language classification, be this phonology, morphology, syntax, or lexicon. But as well as looking to lexical cognates employed across Semitic languages, we might also look to lexemes which, though not formally cognate, are employed to express a similar semantic range or with similar intent and purpose. Turning to the problem of gender 
discord in Biblical Hebrew, Quick suggests interpreting some instances of the phenomenon in light of the semantically comparable instances of mis-match between grammatical and biological gender in Mesopotamian texts, where these occurrences are purposefully and deliberately employed as a form of reverent address to high status women in the Neo-Assyrian court. This has implications for our interpretation of the instances of gender discord in the book of Ruth, which Quick suggests could also be understand as a form of literary strategy.

The self-reflective philologist's task, therefore, is to recognize the limitations of what is perceived as natural and common what in fact represents hegemonic perspectives, and to bring distinct and multiple, uncommon perspectives together. This collection of essays under the rubric of "The Philology of Gender" demonstrate the importance of a gender-inflected philological approach variously through a robust history of the field (Brownsmith), etymological-lexical study (Dolansky, Lilly, Shectman), and issues of grammar and Comparative Semitics (Quick). Comparative work, such as the kind embarked upon in this collection, hones our sense for the uncommon and the embodied, where a sense for language can only come through a critical engagement with the bodies of authors and audiences in their historical and cultural contexts. 